\title{
Feminist Collective Activism in Telangana, South India: Exemplary by the Andhra Pradesh Mahila Samatha Society
}

Ms Julia Guenther ${ }^{+}$

\section{Abstract}

This research aims at contributing to the ongoing debate of feminist standpoint epistemology by introducing a study on feminist collective activism in Sangareddy and Yellareddy, two districts of the newly established 29th state of India, Telangana. The purpose here is to document the work of two sanghams (collectives) by the Andhra Pradesh Mahila Samatha Society (APMSS). The focus lies on songs created by Dalit and indigenous women, which are used as a form of, protest against societal and gender inequality. Those songs contribute in making a positive difference on a local level. Analysis of two group interviews strengthens this argument. The sanghams have shown that despite all societal differences, solidarity among women for a common cause can make a difference in combating social issues on a local level. Taking the APMSS as an example, this research shows that the use of a holistic approach to education to support women in their responses to social issues has an overall positive effect on women. Furthermore, and most importantly, women are strengthened in believing that their life-experiences matter. My research shows that literacy is not necessarily needed to be a successful advocate for women's rights. What is needed, however, is an understanding of local contexts, social issues and ultimately the ability to link them to life-experiences.

Key words: feminist collective activism, songs, Telangana, feminist standpoint epistemology, Dalits

\footnotetext{
${ }^{\dagger}$ University of Vienna, Austria, Email: juliamguenther@gmail.com (C)2014 Guenther. This is an Open Access article distributed under the terms of the Creative Commons Attribution License (http://creativecommons.org/licenses/by/2.0), which permits unrestricted use, distribution, and reproduction in any medium, provided the original work is properly cited.
} 


\section{Introduction}

Feminist standpoint epistemology is an important topic in Gender Studies. This research aims at contributing to the ongoing debate by introducing a study on feminist collective activism in Sangareddy and Yellareddy, two districts of the newly established 29th state of India, Telangana. The purpose here is to document two sanghams (collectives) by the Andhra Pradesh Mahila Samatha Society (APMSS). ${ }^{1}$ Dalit and indigenous women, ${ }^{2}$ who are members of the sanghams, make use of their long tradition of songs and folklore. This research represents songs as a form of protest against societal and gender inequality. It is argued that they contribute in making a positive difference on a local level. Analysis of two group interviews strengthens this argument.

The structure of this research is as follows. First, I discuss the feminist standpoint epistemology, which has been used as the main pillar of the research. In the next section, it attempts to give a brief geographical contextualisation of Telangana. In the third section, the focus lies on feminist collective activism by Dalit and indigenous women who collectively question and oppose social hegemony and the effects of neo-liberal policies.

\section{The Research Framework: Feminist Standpoint Epistemology}

It remains well known that feminist research aims to "give voice to women's lives that have been silenced and ignored, uncover hidden knowledge contained within women's experiences, and bring about women-centered solidarity and social change" (Brooks, 2007: 53).

\footnotetext{
${ }^{1}$ At the time of publication, according to its website http://apmss.org/ the name of the Andhra Pradesh Mahila Samatha Society has not been changed because of the bifurcation of the state into Andhra Pradesh and Telangana.

${ }^{2}$ A Dalit is a designation for a community also referred to as the "untouchables". Dalits are on the lowest strata of the caste hierarchy and are also called caste-less people. Indigenous people belong to culturally distinct groups, which are one of the first inhabitants of the subcontinent (Kumar, 2010).
}

Feminist standpoint epistemology is based on two positions: first, on the understanding, knowledge, experiences and perspectives of women, and second, on the encouragement of women's activism for social change (Brooks, 2007). Besides, feminist standpoint epistemology "is a way of understanding the world, a point of view of social reality, that begins with, and is developed directly from, women's experiences" (Brooks, 2007: 60). As often and rightly argued (Rose, 1997), though, women's experiences can neither be generalised nor can women be subsumed under one category-women are heterogeneous, hence differences among them are important to discuss in feminist based research. Consequently, this means that "knowledge that claims to have universal applicability to all women" (Rose, 1997: 307) ignores the diversity amongst women. Therefore, this paper emphasises on the complexity and interplay of women's identities, which results in a variety of responses to changing framework conditions. Although, I have been introduced to various forms of responses by the sanghams, such as street plays, poster and slogan productions, in the third section of this paper I will only focus on one particular form of protest, namely the creation of songs.

In continuation of the previous point, it is important to note that identity is "based on difference from others but not on separation from others" (Rose, 1997: 314). As Meenakshi Thapan (2009), a sociologist at the Delhi School of Economics, notes, women speak "with a complexity located in the multiplicities of economic deprivation, caste, familial and gender relations. This multiplicity is importantly located in the physical and social conditions of everyday life that women experience" (Thapan, 2009: 2). The present work aims to reflect on such multiplicities and various women's standpoints and to strengthen the ability to understand social, political and economic developments. Sandra Harding (2004), an American philosopher of feminist and postcolonial theory, emphasises on this point in 
her introduction to The Feminist Standpoint Theory Reader:

Each oppressed group [women are understood as an oppressed group] will have its own critical insights about nature and the larger social order to contribute to the collection of human knowledge. Because different groups are oppressed in different ways, each has the possibility (not the certainty) of developing distinctive insights about systems of social relations in general in which their oppression is a feature. (Harding, 2004: 9)

Furthermore, one must note that a woman's locality and position in the time of the experience(s) matter to the analysis (Brooks, 2007). In other words, "women's experiences, perspectives, and the issues they face are constantly evolving and changing across space and time" (Brooks, 2007: 76). This implies further that women's identities are not fixed categories but rather dynamic and evolving in their nature. Therefore, while one of my interview partners identifies herself as a Dalit activist, who embraced Leftist and Marxist ideology in her 20s, she does not do so anymore. Through time and space, the identities and subjectivities of my interview partners have been changing continuously.

As this research derives from a feminist standpoint epistemology (Hartsock, 1983; Brooks, 2007), it seeks to highlight women's collective's efforts to raise awareness on social issues and women's rights. In the context of my research on subjectivity formations and resistances of feminist writers in Telangana, the research is an additional outcome of my encounters in the first half of 2012 with the collectives run by Dalit and indigenous women, where I sought to understand women's everyday lives according to their various social, economic and political backgrounds, and their subjective understandings of resisting against unjust situations and conditions.
The analysis that I am drawing upon derives from group interviews and participatory observations at the women's collective meetings. The group interviews, which took place in Sangareddy and Yellareddy, were held in Telugu, one of the official languages of Telangana. I had the help of a female translator, whose first language was Telugu. Coming from a Dalit background herself, she was able to connect to the women's stories on a different and a deeper level than me. Therefore, she also functioned as a cultural translator, which in my understanding translations always entail. Hence, the selection process of which group to interview was not based on language compatibility but foremost and mainly on women's willingness to share their life-stories with my translator and me. It is important to note that their individual motives varied. Some women have articulated their wish to share their stories without any further expectations from me. Others enunciated their financial hopes and wishes from me, seemingly coming from a 'rich Western country'. However, before conducting the group interviews, I emphasised on the fact that I am not associated to any donor agency nor could I provide any financial support to them but would rather aim to carry forward their positions, struggles, opinions and stories. Having clarified my position, a few women walked away being disappointed understandably so - but the majority of the women stayed and shared their stories with my translator and me.

The described pre-interview process clearly shows that my position as a 'white', 'Western', 'middle-class' feminist researcher in Telangana affected the research. Therefore, I do not claim that my analysis continuously derives from my interview partners' positions as my regional and social background, and therefore my objectivity - in terms of Spivak (Do Mar Castro Varela and Dhawan, 2005), is constructed by my biography. As feminist and post-colonial theorists argue, "all knowledge is produced in specific circumstances and that those circumstances shape it in some way" (Rose, 1997: 305). Hence, the circumstances that I am 
a native of Austria, of a specific economic class and with a specific educational background, that my translator was an educated Dalit from Telangana and that the interviewed women were mainly illiterate, economically poor Dalit and indigenous women from Telangana influenced the unintentional hegemonic dynamics of the interviews. Therefore, situating the positions of everyone involved is crucial in order to engage in a reflexivity process in this research.

Rose (1997) discusses the power structures that exist within a research, especially if the researcher comes from a different geographical and social background. In her essay, "Situating Knowledge: Positionality, Reflexivities and Other Tactics", Rose argues that positioning one's self, which must be actively performed, is the key to knowledge production that does not have universal claim. As discussed above, feminist research is in line with this perspective, which is why a feminist researcher needs to make her/his position visible to one's self as well as to the interviewees (Rose, 1997). This process, although, is not 'of self-discovery' but rather 'of self-construction' (Rose, 1997: 313). In other words, it is important to be aware of one's own constructed identity when one embarks in the research field. It implies that it makes a difference in how one introduces self to the researched, in this research the sanghams. It can be either in a firm, academic way or on a more personal note introducing my long-lasting relation to India. I chose the latter emphasising on my interest in their life-stories, struggles and forms of resistances against social and gender inequality.

Reflecting on these standpoints, I conclude this section with one further important aspect by the feminist geographer Linda McDowell (1992) in which she argues that the relationship between the interviewee and the interviewer is 'a valid part of the research process' (McDowell, 1992: 406). As such, it should be seen as an evolving, maybe even empowering tool for both parties. Relating to this argument, I embrace my fieldwork in Sangareddy and Yallareddy as an enriching and empowering experience. During my visits, I was able to witness the creation of songs, which are seen and used as a tool of collective activism. Women, who are mainly illiterate, are able to transform their pain of violence, oppression, marginalisation and discrimination into powerful songs for social change. Being able to share this process with the attendant women was a moment of interchanging experiences, ideas, opinions and thoughts. In a later stage of this paper, I refer to these songs in greater detail but will now turn to the regional and economic contextualisation of those sanghams.

\section{Telangana: Between Its Long Struggle for a Separate Statehood and Neo-liberal Policies}

The newly established 29th Indian state Telangana inhabits 35 million people, out of which $90 \%$ belong to scheduled caste (SC), scheduled tribes (STs), Other Backward Castes $(\mathrm{OBCs})^{3}$ as well as minority groups, such as Muslims (Rao, 2014). Their living and working conditions have been centrestaged in the debates on a separate statehood for the region of Telangana. The region of Telangana, however, has always been a witness of a number of debates as well as protests against exploitation, land grabbing, poverty and lack of educational and health institutions. The reasons are of historical nature. The so-called Gentlemen's Agreement ${ }^{4}$ in 1956 paved the way for India's first linguistically unified state. Language was the only common identification between the people of Andhra Pradesh. Their economic, educational and social background was heterogeneous. Apart from language, though, the people of Andhra Pradesh were heterogeneous in economical, educational and social background. Since the formation of

\footnotetext{
${ }^{3}$ SC, STs and OBCs are marginalised groups, which are recognised in the Indian Constitution. SC is the term for Dalits, STs is the umbrella term for indigenous groups, OBCs is the umbrella term for socially and educationally disadvantaged caste groups (Bhattacharyya, 2009; Kumar, 2010)

${ }^{4}$ Despite aversion by the people of Telangana, the Gentlemen's Agreement was signed between political leaders - all of them men - of Telangana and Andhra Pradesh to from the state of Andhra Pradesh (Sundarayya, 1972/2014).
} 
Andhra Pradesh, which included the region of Telangana, the diversity as well as gaps between its populations has been visible. Historically, the people of Seemandhra, which combines the regions Rayalaseema and Coastal Andhra, were able to gain from the educational system introduced during the colonial British regime. The people of the Telangana region, however, did not have the same educational opportunities during the Nizams' rule. ${ }^{5}$ Hence, the two regions were merged having different points of departure, Seemandhra being the 'more resourceful, educated, skilled and political dominant' (Rao, 2014: 10) one.

The movement for a separate statehood had since been an ongoing event in the Deccan Plateau. Particularly the book 'We were Making History ...': Life Stories of Women in the Telangana People's Struggle (1989) introduces women's portrays whose lives are not recorded in common history books. It was written to honour the many women who had played a key part in the people's struggle. With the formation of India's 29th state on 02 June 2014, Telangana's separate statehood movement has reached its goal successfully. Kalvakuntla Chandrashekar Rao of Telangana Rashtra Samithi (TRS), the first Chief Minister of Telangana, though, faces a number of economic and social challenges during his first term as the century-long movement arose out of people's needs for a better economic and social situation. Apart from land grabbing, the Green Revolution of the 1970s led to a longlasting damage of cultivatable soil. The goal of the Green Revolution was to limit the production of crops to specific seeds making other crops disappear from the market. Subsequently, multi-national crop companies have neglected traditional farming methods and seeds. Women do the majority of the agricultural labour, which makes them the key resource. However, with the increasing power and entrance of GMO (genetically modified

\footnotetext{
${ }^{5}$ The Nizam was the title of the sovereign of Hyderabad State, which belonged to the Asaf Jah dynasty. The Asaf Jah dynasty ruled Hyderabad State from 1724 until 1947. Seven Nizams were the sovereigns during these two centuries (Zubrzycki, 2006).
}

organism) crop companies in India, women farmers are being pressurised to follow those policies. The sanghams, which I introduce in the following section, strive to overcome those pressures 'which derive from a neo-liberal understanding' (personal communication, Yellareddy, 2012). The women of the sanghams defined neo-liberalism as an accumulation of money and increasing power of financial institutions at the cost of nature and human rights (personal communication, Yellareddy, 2012). This paper defines the beginning of neoliberalism in India with the economic reforms, which began in the 1990s (Ahmed et al., 2011; Patnaik, 2007; Walkers, 2008). However, it is not only the opening of the national to the international economic market (Ahmed et al., 2011; Patnaik, 2007; Walkers, 2008) but also the question of what is Indian. Hence, along with economic reforms, which had a marketdriven agenda, came the question of India's identity as a nation and a people. The economic reforms of the 1990s have caused drastic changes in India. These changes can be seen in the agricultural sector, labour market, cultural influences, technological opportunities (Ahmed et al., 2011; Bhattacharyya, 2009; 2013; Patnaik, 2007; Walkers, 2008), and last but not least in the economic market (Oza, 2006).

\section{Women's Local Responses and Thrive for Social Change}

\section{Andhra Pradesh Mahila Samatha Society: Feminist Consciousness and Collective Activism}

Generally speaking, women's responses to political and social conditions have been witnessed for more than a century in India (Desai, 1948/1991; Forbes, 1998/2000; Forbes, 2005; Jayawardena, 1986; Kumar, 1993; Spivak, 1985). The women's movements' strong contribution to India's independence in 1947 (Forbes, 1998/2000), for example, had a significant influence on the society at large but in particular on women themselves (Desai, 1948/1991; Forbes, 1998/2000; Forbes, 2005; Jayawardena, 1986; Kumar, 1993; Spivak, 1985). Following feminist standpoint epistemology, which uses "women's 
experiences as a lens through which to examine society as a whole" (Brooks, 2007: 59), this section portrays Dalit and indigenous women's experiences with social, political and economic hegemony to understand how it effects their lives. It is thus what feminist standpoint epistemology calls 'the double consciousness' (Brooks, 2007: 63). Double consciousness, firstly, demonstrates social inequality according to women's lived experiences, and secondly, with the insights of women in hegemonic societies, offers possibilities of resistances (Brooks, 2007). In this regard, I highlight how songs carry forward women's voices of collective activism, solidarity among as well as empowerment of women. As feminist standpoint epistemology also bridges the gap between academia/theory and practice/activism (Brooks, 2007), this section aims to contribute to overcoming this gap.

For my fieldwork, I visited two women's sanghams of the Andhra Pradesh Mahila Samatha Society (APMSS) in Sangareddy and Yellareddy, Telangana. The APMSS, which is part of the Mahila Samakhya Project, came into existence in 1993 following the National Policy of Education of 1986 and is financially supported by the Ministry of Human Resource Development, Department of Education. In one of the APMSS reports it reads "[t]he main focus is on empowerment of women through education, to facilitate a process of learning to strengthen the self-image and confidence of women and enable them to take charge of their lives" (APMSS, year unknown: 1). As mentioned above, the key element of empowerment is education. APMSS' approach to empowerment and education is a holistic one. Apart from literacy sessions, an understanding and analysis of issues, such as lack of drinking water and legal assistance, is required. This holistic approach enables women to reflect on the effects of those issues on themselves as well as on their families. Through this thoughtprovoking impulse, the sanghams aim for women to take control over their own lives and environment. Doing so, the women act in a collective effort. In the sanghams, they discuss and work within a triangle, in which personal life, society and state structures are taken into account. With this perspective, they illustrate the vicious cycle of social issues.

The hegemony that government-funded projects entail diminishes in this project once the sanghams become autonomous functioning units in the form of a federation. It is a processoriented procedure, which starts with the village unit, which is the social issue committee on the village level formed by women of the sangham, followed by the cluster unit, which unites representatives of the committee in a cluster. The federation is recessed by the mandal unit, which is formed by representatives of the cluster units and which forms the executive committee of the federation. Once a sangham reaches the structure of a federation, which is a process of about two years, it is financially independent from the Ministry of Human Resource Development. Women of the sanghams are henceforth asked to contribute a small amount towards further development by the federation. For example, the sangham's meeting, in which I participated in Sangareddy, took place in a small house financed and built by the women. This house was built for meetings, evening school and functions. Although the federations are financially independent, they continue to be supervised by the APMSS. In addition, after consulting the sanghams, trainings, development plannings and literacy programmes are conducted by the APMSS.

As written above, health issues, such as lack of drinking water, are a problem, which is being addressed by the sanghams. However, the list of further burning issues is long. Broadly speaking, the sanghams are concerned with child marriage, violence against girl children and women, access to educational and health institutions, political participation and spaces, destruction of natural resources, caste discrimination and the increasing influence of neo-liberal policies in the rural area. As a result, the autonomous federations function as pressure groups to implement social, political, economic as well as women's rights. Their aim 
is to facilitate a second and third generation of young women and men whose understanding of gender equality is deeply rooted in their habits and values and whose living and working conditions are better than their own. Recalling feminist standpoint epistemology, each woman's experience forms a pillar of a collective, which preferably continues through generations. The song Future Generations composed by one of the APMSS' sanghams speaks about it from their particular perspective:

'Children,

Future generation heirs,

Prepared fighters,

We have a road in front of us,

We will not go back; we will not at all go back.

Our aim is women's equality, Our ambition is women's equality.

We will go to our villages,

We will teach about health,

We will gather women,

We will change our village.

We will be $1 / 3$ in the village panchayat committees,

We will make the decisions in the village,

We will tell our brothers and sisters to study.

We will tell them if you study you will know the whole world.'

Although this song speaks from a collective 'we', undoubtedly, when speaking about feminist consciousness and women's collectives, one cannot assume that women are a homogeneous group. Women's experiences are heterogeneous. Therefore, the identity and subjectivity of each member of the collective has to be considered as an individual pillar. Inevitably, the question of how solidarity can be lived in a collective of heterogeneous women arises. The answers I received were positive ones. In the group interviews, women told me that despite having differences in background and opinion, they consider focusing on the collective power for positive societal changes more important. In the following section, I show how this collective power is translated into songs, which function as a form of protest.

\section{Songs as a Form of Protest}

The sanghams of the APMSS have composed a number of songs on issues such as land grabbing, agriculture, neo-liberal policies, identity, health, politics and education. With the composed songs, the women advocate their positions on critical questions concerning their daily lives. They function as a collective tool to address the concerned issues. Created at the sanghams' meetings, the songs illustrate processes of discussions, analysis and opinions. It is the women's pain that is being expressed in a transformative tool (group discussion, Sangareddy, 2012). The songs give the women the freedom to express themselves under the collective anonymity. It allows them to articulate what might be diminished otherwise. Women start every meeting with a song encouraging themselves to continue their struggle for a gender just and caste free society. Besides performing the songs at their meetings, they sing at demonstrations, village gatherings and functions. Therefore, the audiences vary but the addressees are clear: politicians, opinion leaders and decision makers. Although songs are not the only possibility to address issues, the women decided to carry forward an old tradition of their ancestors (group discussion, Sangareddy, 2012). Therefore, the songs are also a legacy of tradition, culture and language of Telangana. The few examples, which I am introducing in this paper, are literal translations by my translator. The originals are performed in a regional Telugu dialect of Telangana.

The following lines are taken from their song titled The Village is Ours.

'The village is ours,

This street is ours,

This hamlet is ours.

Housework is ours,

The outside work is ours.

We work on the paddy-plantation and do paddy harvesting. 
What is this problem? Oh how much back pain.

Without food our problems are growing, Bending and so much work,

They are telling us that this work is common to all.

What is this pain, what is our life?

More and more babies are born but our strength decreases.

If white discharge becomes more, it may cause cancer,

Medicine is available but no money in our hands to buy it.

Elder sister come, brother and sister come,

Come we will know the unknown issues.

We have so many government facilities,

Come we will know them all.

Our health will become good and we will get relief from our pain.' (A.P.

Mahila Samatha Society, year unknown)

This song was introduced to me as one of their most important songs because it talks about a number of issues. The women have composed it in such a manner to show how interrelated social issues are. It is, thus, the vicious cycle that they want to break by looking at the triangle of personal life, society and state. The issue of caste and class is one that cuts across all their activities and hence it is also an inevitable element of this song. Land-grabbing, which took place in the region of Telangana for centuries, is also being addressed, though in a subtle way. The women claim their property but show in the following sentences that they work as labourers for landlords. The lack of working rights leads to insufficient healthcare and increasing health issues. This song, similar to others, does not only address social issues but also of strategic possibilities for social development. In this song, the women suggest to claim their right for information given to them by the Right to Information Act. In the year 2002, the Indian government passed the Right to Information Act to give citizens access to information by public authorities regardless of caste, class, religion or sex. With this access, the sanghams can follow up on their rights and claim them from the respective people, institutions and authorities.

The following song called The Poor Daily Wage Labourer stresses on the situation of labourers further and emphasises on the need of solidarity to claim their rights.

'Poor daily wage labourers should have a union, One society, oh sister, One union, oh sister. We are the samatha, oh sister. Search and see the world.

There are two things,

Rich people, oh sister, And poor people, oh sister.

Cobblers, barbers, carpenters and goldsmiths,

No caste and religious differences, oh sister.

We are all one, oh sister.

...

We have to discuss problems of our village.

Step forward, oh sister, We should be united, oh sister.

We have held night meetings to increase our knowledge, oh sister.

We have to know our position, oh sister. That is our biggest aim, oh sister.

We all belong to samatha, oh sister.' (A.P. Mahila Samatha Society, year unknown)

The theme of this song is a continuation of the previous one. Here, the women suggest that solidarity, in form of a collective or trade union, is the best option to fight day-to-day caste and class discrimination. It is a song that is goaloriented with a brief introduction to the issue.

Apart from listing social issues, these songs suggest that a positive societal change is possible if women form in a collective, are informed about their rights and stay united in spite of their differences. Together these songs provide an important insight into the living and working conditions of the women but are also indicative of the positive effects of protest songs. The successes on a local level have been worth noticing. Two of the most important 
successes are that women's participation in decision-making processes has increased and violence against women has decreased. Therefore, it can be concluded that it is the effort of the collective that makes such successes possible.

\section{Conclusion}

This research has highlighted the importance of feminist standpoint epistemology with the collectives of the APMSS as examples. It has several practical implications. Firstly, it points to the importance of the relation between the interviewer and the interviewee. Secondly, it argues that the researcher's position influences the dynamics of the research. Finally, it brings the lives of the women into focus. Taking the APMSS as an example, this research has shown that the use of a holistic approach to education to support women in their responses to social issues has an overall positive effect on women. Furthermore, and most importantly, women are strengthened in believing that their lifeexperiences matter. My research shows that literacy is not necessarily needed to be a successful advocate for women's rights. What is needed, however, is an understanding of local contexts, social issues and ultimately the ability to link them to life-experiences.

The sanghams have shown that despite all societal differences, solidarity among women for a common cause can make a difference in combating social issues on a local level. In other words, a union, which the song The Poor Daily Wage Labourer advocates for, can provide space for a bigger understanding. As Hartsock (1983) describes feminist standpoints having 'liberatory possibilities' (Hartsock, 1983: 317), I argued in this research that solidarity among women can have similar potentials. However, solidarity among women and collectives, such as the ones of the APMSS, are not the only possibilities to protest against ongoing inequality between men and women, castes, classes and religions.

It is important to notice that the current study was limited to the collectives of the APMSS. However, further research needs to be done to establish a stronger understanding of protest songs and their implications. Also, further work needs to highlight the lives of Dalit and indigenous women of Telangana. Hence, this essay can be understood as a small contribution to this effort.

\section{References}

Ahmed, Waquer, Amitabh Kundu, and Richard Preet, eds. (2011). India's New Economic Policy: A Critical Analysis. New York: Routledge

Bhattacharyya, R. (2009). Examining the Changing Status and Role of Middle Class Assamese Women: Lessons from the Lives of University Students, PhD thesis, Newcastle University, UK

Bhattacharyya, R. (2013). Are we empowered? Stories of young Indian working women. Saarbrücken, Germany: Lap Lambert Academic Publishing [ISBN: 978-3-659-20580-4]

Brooks, A. (2007). Feminist Standpoint Epistemology. Building Knowledge and Empowerment Through Women's Lived Experience. In S. N. Hesse-Biber et al. (eds.), Feminist Research Practice. A Primer, Thousand Oaks: SAGE Publications [ISBN: 978-14-1298427-0], pp. 53-82

Desai, A.R. (1948/1991). Movement for the Emancipation of Women. In A. R. Desai (1948/1991) Social Background of Indian Nationalism. Mumbai: Popular Prakashan Private Limited, [ISBN: 978-81-7154-667-1], pp. 273-280

Do Mar Castro Varela, M.; Dhawan, N. (2005). Postkoloniale Theorie. Eine kritische Einführung. Band 12, 1. Auflage, Bielefeld: transcript Verlag (ISBN: 3-89942-337-2)

Forbes, G. (1998/2000). Women in Modern India. The New Cambridge History of India. New Delhi: Cambridge University Press (ISBN: 9780521653770)

Forbes, G. (2005). Caged Tiger. "First Wave" Feminists in India. In G. Forbes (2005) Women in Colonial India. Essays on Politics, Medicine, and Historiography. New Delhi: Chronicle Books D.C. Publishers [ISBN: 81-8028-017-9], pp. 1127 
Future Generations (year unknown), Hyderabad, India: APMSS.

Harding, S (2004). Introduction: Standpoint Theory as a Site of Political, Philosophic, and Scientific Debate. In S. Harding (ed.). The Feminist Standpoint Theory Reader: Intellectual and Political Controversies, New York: Routledge [ISBN: 0-415-94500-3], pp. 1-15

Hartsock, N. C. M. (1983). The Feminist Standpoint: Toward a Specifically Feminist Historical Materialism. In C. R. McCann et al. (eds.) (2010) Feminist Theory Reader: Local and Global Perspectives, 2nd Edition, London: Routledge [978-04-155-2102-4], pp. 316-331

Jayawardena, K. (1986). Women, Social Reform and Nationalism in India. In K. Jayawardena (1986): Feminism and Nationalism in the Third World. New Delhi/London: Kali for Women/Zed Books Ltd [ISBN: 978-0862322656], pp. 73-108

Kumar, R. (1993). The History of Doing. An Illustrated Account of Movements for Women's Rights and Feminism in India 1800-1990, New Delhi: Kali for Women (ISBN: 0-85107-76-9)

Kumar, R. (2010). Dalit Personal Narratives. Reading Caste, Nation and Identity, Hyderabad: Orient Black Swan (ISBN: 978812504250 1)

Lalita, K.; Kannabiran, V., et al. (1989). ,We Were Making History ...': Life Stories of Women in the Telangana People's Struggle, New Delhi: Kali for Women (ISBN: 81-85107-12-2)

McDowell, L. (1992), Doing Gender: Feminism, Feminists and Research Methods in Human Geography, Transactions of the Institute of British Geographers, New Series, 17 (4), pp. 399-416

Oza, R. (2006). The Making of Neoliberal India. Nationalism, Gender and the Paradoxes of Globalization, New Delhi: Women Unlimited (ISBN: 81-88965-32-4)

Patnaik,Utsa (2007). Neoliberalism and rural poverty in India, Economic and Political Weekly, 42(30), 3121-3150

Personal Communication (2012): group discussion, Sangareddy.
Personal Communication (2012): group discussion, Yellareddy.

Rao, H. C. H. (2014). The New Telangana State: A Perspective for Inclusive and Sustainable Development, Economic and Political Weekly, XLIX (9), pp. 10-13

Rose, G. (1997). Situating Knowledges: Positionality, Reflexivities and Other Tactics, Progress in Human Geography, 21(3), pp. 305320

Spivak, G. C. (1985). Subaltern Studies: Deconstructing Historiography. In D. Landry; G. MacLean (eds.) The Spivak Reader. Selected Worls of Gayatri Chakravorty Spivak. New York/London: Routledge [ISBN: 9780415910019], pp. 203-235

Sundarayya, P. (1997/2014). Telangana People's Struggle and its Lessons, New Delhi: Foundation Books (ISBN: 978-93-82993-85-8)

Thapan, M. (2009). Living the Body. Embodiment, Womanhood and Identity in Contemporary India. New Delhi/Los Angeles/London/Singapore/Washington DC: Sage Publications (ISBN: 978-81-7829-901-3)

The Poor Daily Wage Labourer (year unknown), Hyderabad, India: APMSS.

The Village is Ours (year unknown), Hyderabad, India: APMSS.

Together We Make a Path ... The Journey from Sangham to Mahila Court (year unknown). Together We Make a Path ... The Journey from Sangham to Mahila Court, Hyderabad, India: APMSS.

Walkers Katy Le Mons (2008). Neoliberalism on the Ground in Rural India: Predatory Growth, Agrarian Crisis, Internal Colonization, and the Intensification of Class Struggle, The Journal of Peasant Studies, 35(4), 557-620

Zubrzycki, J. (2006). The Last Nizam. The Rise and Fall of India's Greatest Princely State, Sydney: Macmillan (ISBN: 13978144721889 0) 


\section{Acknowledgement}

A first version of this paper was presented at the 17th World Congress of the International Union of Anthropological and Ethnological Sciences in Manchester in August 2013. I thank the University of Vienna for granting me a stipend to attend the conference. The original title of the paper was 'Changing Framework Conditions and Local Responses of Marginalized Women in Andhra Pradesh, India'. 